\title{
Non-Wycliffite Bible Translation in \\ Oxford, Trinity College, 29 and Universal History Writing in Late Medieval England
}

\author{
Cosima Clara Gillhammer, Trinity College, Oxford \\ cosima.gillhammer@ell.ox.ac.uk
}

\begin{abstract}
The late-fifteenth-century Middle English manuscript Oxford, Trinity College, 29 contains a universal history of the world, compiled from diverse religious and secular source texts and written by a single compiler-scribe. A great part of the text is focused on Old Testament history and uses the Vulgate as a key source, thus offering an opportunity to examine in detail the compiler's strategies of translating the text of the Bible into the vernacular. The Bible translations in this manuscript are unconnected to the Wycliffite translations, and are non-reformist in their interpretative framework, implications, and use. This evidence is of particular interest as an example of the range of approaches to biblical translation and scholarship in the vernacular found in late medieval English texts, despite the restrictive legislation concerning Bible translation in fifteenth-century England. The strategies of translating the biblical text found in this manuscript include close word-by-word translation (seemingly unencumbered by anxieties about censorship), as well as other modes of interaction, such as summary, and exegesis. This article situates these modes of engagement with the Bible within a wider European textual tradition of including biblical material in universal history writing.
\end{abstract}

\section{Bible Translation in Fifteenth-Century England}

A significant part of earlier scholarship on Bible translation in fifteenth-century England has been dominated by views which present a dichotomy between Wycliffite and non-Wycliffite texts and readers. These categories are frequently subsumed under the labels of heterodoxy (i.e. Wycliffite and reformist theological thought) vs. orthodoxy (i.e. non-Wycliffite and conservative theological thought). ${ }^{1}$ Much theological and religious writing of the fifteenth

\footnotetext{
${ }^{1}$ My use of these terms follows the current consensus in Wycliffite studies. It is a given that these terms are of use in categorising a complex set of attitudes and practices, but describe tendencies rather than absolutes. The areas of overlap between 'orthodoxy' and 'heterodoxy' in terms of intellectual
} 
century has been considered in relation to these categories, and within the context of censorship imposed by Archbishop Arundel's Constitutions of Oxford (1409), which prohibited both the creation and the perusal of any full or partial translation of Scripture into the vernacular newly made during or after the time of John Wyclif, unless the translation had been approved by the ecclesiastical authorities. ${ }^{2}$ The ensuing climate of censorship in fifteenth-century England has been subject to wide-ranging scholarly investigation in the wake of Nicholas Watson's much-discussed article, in which he argued that Arundel's Constitutions led to an atmosphere which "inhibit[ed] the further composition of most kinds of vernacular theology” (1995: 825). More recent investigations have somewhat relativised Watson's findings, but the extent to which the climate of censorship affected different authors in different social and geographical spheres, especially in the late fifteenth century, is still largely unclear. ${ }^{3}$

In this context, the evidence to be gained from non-Wycliffite texts which translate biblical texts into English is of particular relevance. An example of such a text is contained in the latefifteenth-century manuscript Oxford, Trinity College, 29 (afterwards T). The manuscript contains a seamless universal history of the world which starts with the creation of the world and breaks off incomplete at the time of Hannibal. ${ }^{4}$ Somewhat unusually, the history is compiled from both manuscript and print sources. The prints used as source texts are Caxton's Polychronicon (which provides the framework for the universal history in $T$ ) and de Worde's Information for pilgrims unto the Holy Land. The manuscript sources include the Vulgate, the Canterbury Tales, a Holy Cross Legend, Peter of Poitiers's Compendium historiae in genealogia Christi, Gower's Confessio Amantis, a translation of Jacques Legrand's Book of Good Manners, and Mandeville's Travels. The manuscript is written in a single hand (the compiler being the same person as the scribe), and is likely to originate from an Augustinian

thought, textual evidence, and manuscript ownership have been widely discussed. See, for instance, Hudson (1988: 421-430), Dove (2010: xix-Xx), and Solopova (2016a)

${ }^{2}$ Cf. Article 7, quoted and translated in Dove (2007: 35-36).

${ }^{3}$ For a range of more recent responses to Watson, see the studies in Gillespie and Ghosh (2011).

${ }^{4}$ The text is edited in my forthcoming edition of Oxford, Trinity College, MS 29 with Middle English Texts (Gillhammer forthcoming). Aspects of the text are discussed in Edwards (1980: 117), Harris (1983: 27-40), Kennedy (1989: 2662), Harris (1993), Harris (1998), Ogilvie-Thomson (1991: 95-96), Mosser (2010), Wakelin (2014: 175-178), and Gillhammer (2019). The most up-to-date description of the manuscript is contained in Gameson (2018: 219-222). 
context, possibly in East Anglia. ${ }^{5}$ The use of printed sources provides a terminus post quem of 1482 for the text.

As a great part of the text is focused on Old Testament history, significant portions of the manuscript contain translations and summaries of biblical material. The sections in $T$ which use biblical material fall into three distinct categories:

a) Sections which translate from the Vulgate directly and closely, either with or without inclusion of the Latin text (hereafter described as 'direct' translations),

b) Sections which are based on biblical material but summarise it rather than directly translating the text,

c) Sections which provide a commentary and exegesis of the biblical text.

The sections in the first category are of particular interest in the context of the controversy surrounding Bible translation in late medieval England, as the translations in $T$ are unrelated to the Wycliffite Bible, and as $T$ in general shows no heterodox tendencies. There is no neat and clear divide between orthodox and heterodox readers and owners of biblical books in late medieval England. As Anne Hudson's seminal study (1988: 444) has shown, Archbishop Arundel's restrictive legislation regarding Bible translations was only enforced sporadically, and there is evidence of ownership of Wycliffite translations by undoubtedly orthodox readers (Solopova 2016a, 2016b). There were, of course, also some practical difficulties in discerning heterodox tendencies in any specific manuscript (Hudson 1988: 422). Around the time of the compilation of $T$ in the late fifteenth century, the English church had undergone significant developments since Arundel's time. Vincent Gillespie (2011: 14) has pointed out the shift in perspective during and after Henry Chichele’s time as archbishop (1414-1443), a man who was part of a "generation [which] shared more common ground with the Wyclivisiti than Arundel's”. Nonetheless, Chichele’s successor John Stafford pursued a very restrictive policy on vernacular bibles (De Hamel 2001: 178). Arundel's Constitutions formally remained in force until 1529, hence covering all new translations of the Bible including Tyndale's, and ownership of vernacular scripture was used as incriminating evidence in heresy trials (Hudson 1988: 231).

The nature of the text in $T$ shows that its compiler was a highly educated, theologically competent individual. ${ }^{6}$ It is unlikely that such a compiler would have been unaware of the fact

\footnotetext{
${ }^{5}$ The evidence for a compiler-scribe, as well as for the manuscript's origin, is assessed in my forthcoming edition with Middle English Texts.
} 
that translation of the Vulgate into the vernacular was a particularly contentious issue in the context of the Wycliffite controversy. Nonetheless, he did not have any qualms about composing this vernacular account of Old Testament history, substantive parts of which were either translated directly from the Vulgate, or based upon it more loosely. Despite these translations, there is no indication that the compiler had any Wycliffite sympathies, and the material in $T$ is entirely conservative in its theological content and implications. Due to the compiler's sophisticated use of source texts and the variety of modes of interacting with the biblical text, the number of translated passages in $T$ is somewhat difficult to quantify. At an estimate, however, more than 2000 lines (out of a total of 11739 lines) are translated from or based on the Vulgate without any intermediary sources (as opposed to passages which are based on intermediary sources containing biblical material, such as Caxton's Polychronicon). $T$ provides, therefore, an ideal opportunity, for a case study which allows us to examine one way in which non-reformist translation of the Bible was conducted in late fifteenth-century England.

\section{Modes of Interaction with the Biblical Text in $T$}

\subsection{Direct Translation}

\subsubsection{English Translation with Inclusion of the Full Latin Text}

As shown in the overview above, passages in category a) translate from the Vulgate directly and closely, in many cases with a full or partial inclusion of the original Latin text. Throughout $T$, we find different ways of pointing towards the Latin text, and to the manuscript's status as containing an English translation. In many cases, the full Latin quotation is given in a display script, which is then followed by the translation in a more current hand. This does not hide but highlights the presence of the translation, which at the very least had the potential to be perceived as illegal according to Arundel's Constitutions.

\footnotetext{
${ }^{6}$ See Gillhammer (forthcoming), for a discussion of the complex compilatory strategies and theological expertise displayed in $T$.
} 


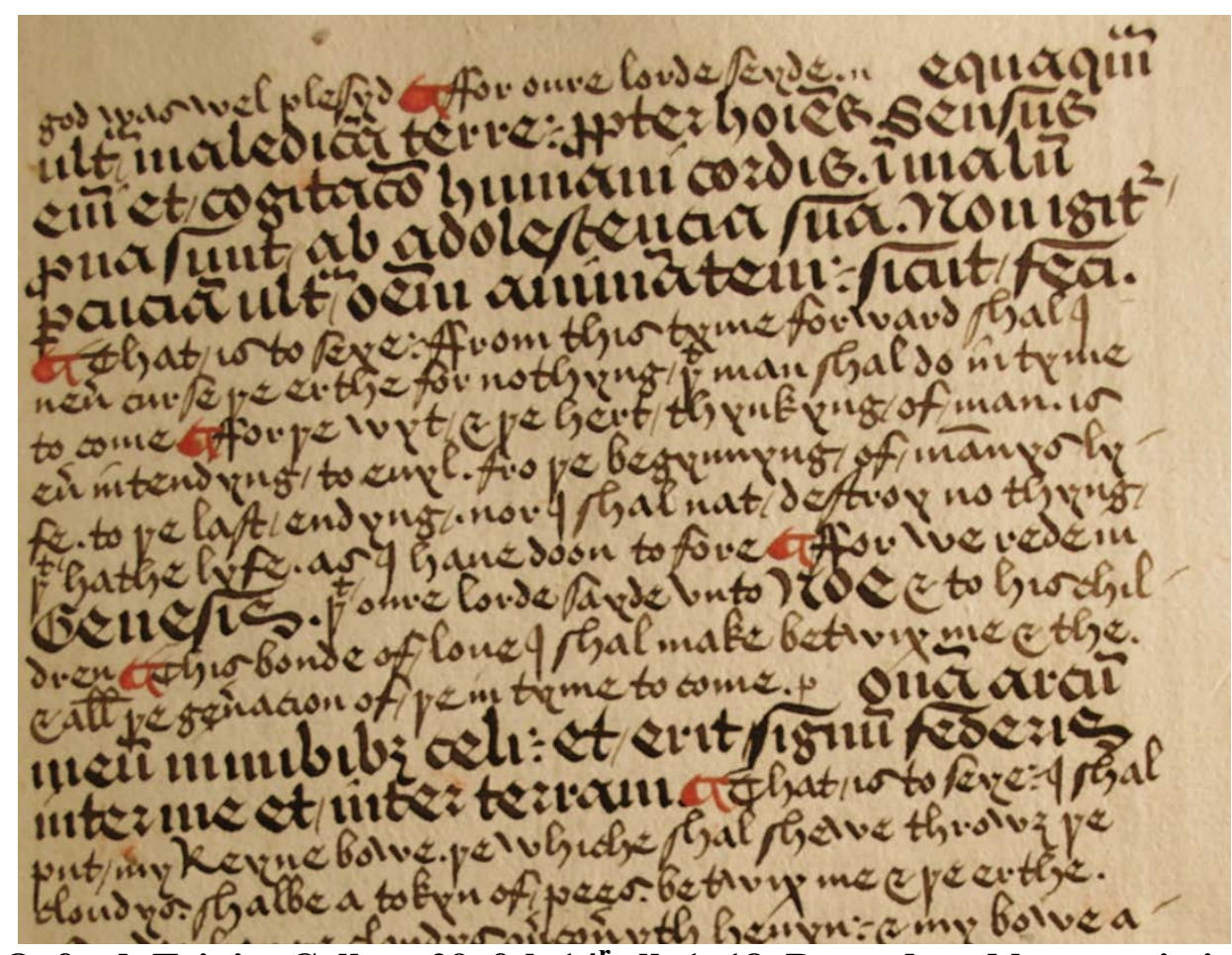

\section{Figure 1: Oxford, Trinity College 29, fol. $14^{\mathrm{r}}$, ll. 1-18. Reproduced by permission of the President and Fellows of Trinity College, Oxford.}

Figure 1 shows a section from Genesis, which describes God's promise after the Flood never again to destroy mankind through water in time to come. Several parts of this section are quoted directly from the Vulgate, and followed by a translation. On each occasion, the Latin quotations are presented in a 'Bastard' Secretary, which is a higher-grade script than the more current hand used for the English translation. ${ }^{7}$ On a visual level, the authority of the Latin text is thus emphasised through the hierarchy of scripts, so that at a brief glance it is clear even to non-Latinate readers that the biblical text is being translated into the vernacular. ${ }^{8}$ Its status as a translation is also indicated on a textual level by introduction of the phrase That is to seye: ${ }^{9}$

\footnotetext{
${ }^{7}$ I follow the terminology of Parkes (1969: 19).

${ }^{8}$ On the hierarchy of scripts, see Parkes (1969).

${ }^{9}$ The phrase pat is to seye (including spelling variants) occurs 77 times in $T$. It typically introduces either translations or explanations of the preceding content. In 37 instances it functions as a metatextual signal for a direct translation, often of a Latin quotation from the Bible, into English, although there are exceptions to this rule (e.g. "as it aperyth in pe xj chapiter of pe boke of pe dedys of Appostlys, pat is to seye, in Actibus appostolorum” (1l. 8338-8339)). The phrase only precedes direct translations and is not used to introduce summaries of biblical material in $T$. In 40 other instances the phrase does not introduce a translation but rather an explanation or a specification of the preceding content (e.g. "For fyue wycked cytees pat pere were adreynt and ybrent to asshes, pat is to seye,
} 
${ }^{\left[{ }^{[83]}\right.}$ For oure Lorde seyde, "Nequaquam ultra maledicam terre propter ${ }^{[804]}$ homines sensus enim et cogitacio humani cordis in malum prona sunt ${ }^{\left[{ }^{805]}\right.}$ ab adolescencia sua. Non igitur percuciam ultra omnem animantem ${ }^{[806]}$ sicut feci.” That is to seye, "From this tyme forward shal I neuer curse pe ${ }^{[807]}$ erthe for nothyng pat man shal do in tyme to come. For pe wyt and pe hert ${ }^{[808]}$ thynkyng of man is euer intendyng to euyl, fro pe begynnyng of mannys ${ }^{\left[{ }^{[09]}\right.}$ lyfe to pe last endyng. Nor I shal nat destroy no thyng pat hathe lyfe as I ${ }^{[810]}$ haue doon tofore.” ${ }^{10}$

The section emphasised by the display script is Genesis 8:21 in the Vulgate, which is quoted in full, and followed by a full translation. This translation shows no marked similarity of wording or syntax to either the Early or the Late Versions of the Wycliffite Bible, which render the same verse as follows:

EV:

I shal no more curse to the erthe for men, the witt forsothe and the thouzt of mannus herte ben redi in to yuel fro his tyme of waxyng; therfore I shal smyte no more ech soule lyuynge as Y haue don

\section{LV:}

Y schal no more curse the erthe for men, for the wit and thouzt of mannus herte ben redi in to yuel fro $30 n g$ wexynge age; therfore $\mathrm{Y}$ schal no more smyte ech lyuynge soule as $\mathrm{Y}$ dide $^{11}$

Sodom, Gomor, Aldena, Salame, and Segor.”, ll. 1512-3). In all cases, therefore, the phrase marks sections which help to facilitate comprehension, either through translation or explanation.

${ }^{10}$ Line numbers in square brackets refer to my forthcoming edition of the text. The text is edited according to the following policy: The letters $u, v, p, 3, i$, and $j$ have been preserved as they occur in the manuscript. The ambiguous majuscule $I / J$ is treated as $i$ throughout. Double $f$ is represented as capital $F$. The display script used in $T$ for names and specific phrases is indicated by bold type in an attempt to mirror the use of the hierarchy of scripts in $T$. Abbreviations have been silently expanded throughout the text. Punctuation, capitalisation, paragraphing, and word division have been modernised.

${ }^{11}$ All quotations from the Wycliffite Bible in this article are taken from Forshall and Madden’s edition (1850). 
Compared to the Wycliffite versions, the translation in $T$ is arguably freer and more idiomatic, and less restricted by the Latin syntax. ${ }^{12}$ The phrase propter homines is translated literally in the Wycliffite Bible as for men in both versions, while $T$ has the more extensive for nothyng pat man shal do in tyme to come (1. 807), which interprets the meaning behind the words of the Latin version as referring to man's deeds, thus clarifying the meaning of the phrase. ${ }^{13}$ In a similar way, ab adulescentia sua is translated rather freely as fro pe begynnyng of mannys lyfe to pe last endyng (1l. 808-809) in T, which here interprets the time span during which man's heart is inclined to evil as man's entire life, and mentions explicitly the beginning and the end of man's life. The Wycliffite Bible, again, renders the Latin syntax more literally here and translates fro his tyme of waxyng (EV) and fro zong wexyng age (LV). The Latin in malum prona sunt is translated by the phrase ben redi in to yuel in both Wycliffite versions, which translates both the adjective prona and the preposition in very literally, whilst $T$ has the construction euer intendyng to euyl (1. 808), which follows the Latin syntax less closely, and is arguably more idiomatic. ${ }^{14}$ Clarity and idiomaticity appear to be the aims of these Bible translations in $T$, and in pursuing this aim the compiler is far less literal than even the Late Wycliffite Version (which is more idiomatic than the Early Version).

\footnotetext{
${ }^{12}$ I use the term 'literal translation' in this article as referring to similarities between the Latin and English versions regarding their lexical, grammatical, and syntactical choices. On translation technique in the Wycliffite versions and the greater literalness of $\mathrm{EV}$, as opposed to the greater idiomaticity of LV, see Dove (2007: 137-152) and Hudson (2017).

${ }^{13}$ On medieval translation theory, see, amongst others, the Prologue to Nicholas of Lyra's Postilla Literalis, transl. in Minnis et al. (1991: 266-270). See also the detailed theoretical and methodological thoughts on Bible translation from Latin into English contained in the General Prologue to the Wycliffite Bible (Dove 2010: 3-85).

${ }^{14}$ There are 6 attestations of the redi into-construction in the $M E D$, nearly all of which are from the Wycliffite Bible (translating pronus or paratus), with the single exception of one instance in Reginald Pecock's Repressor of Over Much Blaming of the Clergy (1449). By contrast, intendyng to (+ noun phrase) is attested in a wider range of texts, including the Paston letters and Letterbook $K$ in the City of London Records Office. This indicates that redi into was chiefly in use as a translation of specific Latin constructions, whilst intendyng to was used in a wider range of contexts, and would likely have been perceived as the more idiomatic choice.
} 


\subsubsection{English Translation with Partial Inclusion of the Latin Text}

In some cases, $T$ does not provide a full Latin quotation which is then translated fully, as in example [1]. A section containing the account of God making peace with man after the Flood and creating the rainbow as a token of this peace, does not give full quotations from the Vulgate but rather gestures towards the source text in a different way:

[2]

${ }^{[810]}$ For we rede in Genesis pat oure Lorde sayde vnto Noe ${ }^{[811]}$ and to his children, "This bonde of loue I shal make betwix me and the, and ${ }^{[812]}$ alle pe generacion of pe in tyme to come." "Ponam arcum meum in ${ }^{[813]}$ nubibus celi, et erit signum federis inter me et inter terram." That is to ${ }^{[814]}$ seye, "I shal put my reyne bowe, pe whiche

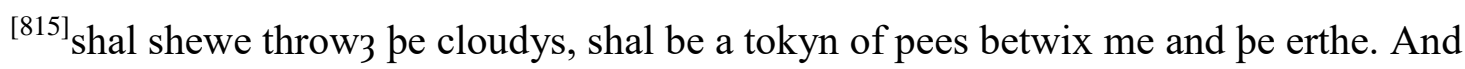
whan pe cloudys ${ }^{[816]}$ ouercoueryth heuyn and my bowe aperyth in pe cloudys, than shal I ${ }^{[817]}$ remembyr pe promys of pees pe whiche I made to the and to thy ${ }^{[818]}$ generacioun and to alle lyuyng peple in tyme to come. And pere shal neuer ${ }^{\left[{ }^{819]}\right.}$ water drenche furthermore, nothyr man ne beest, for my bowe shal be in pe ${ }^{[820]}$ cloudys, and I shal se yt. And than shal I remembyr pe euerlastyng pees pe

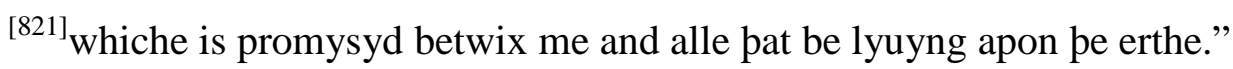

The source of this section, Genesis, is given at the beginning, making it clear that what follows is biblical material. This entire section (from This bonde of loue onwards) is, in fact, a translation of Genesis 9:12-16 from the Vulgate, but only a small part of it is quoted in Latin. As in the previous example, this Latin quotation is followed by That is to seye (ll. 813-814), indicating that what follows is a translation of the Latin. However, the remainder of the section printed above did not contain any indicators as to its status as translation until I added editorial punctuation. ${ }^{15}$ In practice, it would be difficult for the readers to tell where the translation ends in the manuscript, unless they were to compare it with the Vulgate directly. It seems as if the Latin quotation here functions as a kind of cue. Rather than providing a means of accessing the passage fully in both languages, its function might rather be to license the presence of an English translation, and point towards the existence of the Latin authoritative source.

\footnotetext{
${ }^{15}$ The original punctuation in the manuscript does not emphasise the presence of the translation in any specific way.
} 
Once again, this translation does not show any similarities to the Wycliffite Bible, and is less literal in its approach to translation. Whilst the translation of signum federis in the Wycliffite versions follows the usual meaning of foedus as a 'legal agreement or bond', ${ }^{16}$ emphasising the resulting peace (EV: signe of couenaunt of pees; LV: signe of boond of pees), $T$ translates semantically more freely as bonde of loue (1. 811). $T$ also adapts the pronouns in this passage to the particular requirements of the narrative framework in $T$ : God here appears to be speaking to Noah first and foremost, addressing him in the second person pronoun singular (the, l. 811), thus creating a greater immediacy than the Latin plural vos (Gen $14: 12){ }^{17}$

A similar adjustment of the biblical text to achieve a particular dramatic effect in $T$ can be found in a passage translating Genesis 3:9-13:

\section{[3]}

${ }^{[132]}$ And than oure Lorde callyd ${ }^{[133]}$ Adam and seyde, “Adam Adam ubi es,” 'Adam, Adam, where art ${ }^{[134]}$ thow?' And than Adam spake to oure Lorde and seyde, “A, Lorde, I herde ${ }^{[135]}$ thy voyce welle but I dred to answere vnto pe because I was nakyd, and ${ }^{[136]}$ perfor I hyd me." Than seyde oure Lorde, "Who shewyd pe or tolde pe pat ${ }^{[137]}$ thow were nakyd but pat thou hast ete of pe tree whiche I forbad be thou ${ }^{[138]}$ shuldyst nat ete of?" Than seyde Adam, "Lorde pe woman whiche thou ${ }^{[139]}$ ordeynyst to be my felow gaue me of pe tree and I ete yt.” Than oure Lorde ${ }^{[140]}$ askyd pe woman why she had so doo. And she seyde, "Lorde pe serpent ${ }^{[141]}$ deceyuyd me and causyd me to ete yt."

Similar to example [2], this passage uses a short Latin quotation as a cue, perhaps to legitimise the presence of the translation. It then proceeds to translate the rest of the biblical text without any clear marker of its being a translation. Interestingly, the Vulgate merely has Ubi es in Gen 3:9, whilst $T$ quotes this as Adam Adam ubi es (l. 132), with the repetition of

\footnotetext{
${ }^{16}$ foedus ${ }^{3}$, DMLBS.

${ }^{17}$ It is, of course, a given that there is a great deal of variation in medieval copies of the Vulgate, and that not all of these variants are reliably noted in modern critical editions. As the following analysis will show, however, such changes in $T$ appear systematic and serve to create a specific dramatic effect. It is, therefore, likely that they were introduced by the compiler of $T$, rather than being the result of textual variation in the Latin exemplar. On the difficulty of tracing the different forms of the text of the Vulgate in the late Middle Ages, see, for instance, Hudson and Solopova (2017).
} 
Adam's name heightening the intensity of God's call. It is, of course, possible that the compiler was here working from a variant copy of the Vulgate, ${ }^{18}$ but there are reasons to assume that these changes were introduced by the compiler himself. Similar changes appear elsewhere in the translations from the Bible in $T$, e.g. where the Vulgate has Vocem tuam audivi in paradiso, this is translated as A, Lorde, I herde thy voyce welle (ll. 134-135). The interjection $A$ here heightens the liveliness of the narrative in a similar way to the repetition of Adam's name, which suggests that these changes are the result of the compiler's subtly adapting the biblical text and translation to his narrative purposes. These interjections show that the compiler had an ear for dialogue and used these additions to heighten the immediacy and dramatic quality of the text.

It is worth noting that in example [3], there is no insertion of pat is to seye to indicate that the Latin is being translated. Although, as discussed above, biblical translations are often marked in this way throughout $T$, there are some passages which do not use this phrase to introduce a direct translation. For instance, a section translated from the Book of Job 1:21 describes Job’s reaction after all his worldly possessions have been taken from him:

\section{[4]}

${ }^{[6049]}$ And when ${ }^{[6050]}$ messengeris come vnto hym and seyde pat his goodys and his childryn ${ }^{[6051]}$ were destroyed, he seyde ful mekely, "Dominus dedit dominus abstulit.” [6052]،The good Lorde hathe geuyn alle thyngis, and pe good Lorde hathe takyn ${ }^{[6053]}$ alle thyngis.' "Sicut domino placuit ita factum est.” 'As it plese pe good ${ }^{[6054]}$ Lorde, so be yt.' "Sit nomen domini benedictum.” 'His name be blissyd. ${ }^{\text {,9 }}$

In this section, we find sentence-by-sentence glossing of the Latin, so that Latin quotations alternate with English translations. Even though no markers such as pat is to seye are used, the glossing structure, in connection with the visual alternation between display script and lower-grade script (cf. Figure 2) would make it quite obvious even to non-Latinate readers that the Latin is being translated one sentence at a time.

\footnotetext{
${ }^{18}$ I use Weber and Gryson’s edition of the Vulgate (2007) for purposes of comparison in this article. Weber and Gryson record the variant Adam ubi es (2007: 7) for this verse, but none of their collated manuscripts contain a doubling of Adam.

${ }^{19}$ The sentence "Sicut domino placuit ita factum est" does not appear in all manuscripts of the Latin text (Weber and Gryson 2007: 733).
} 


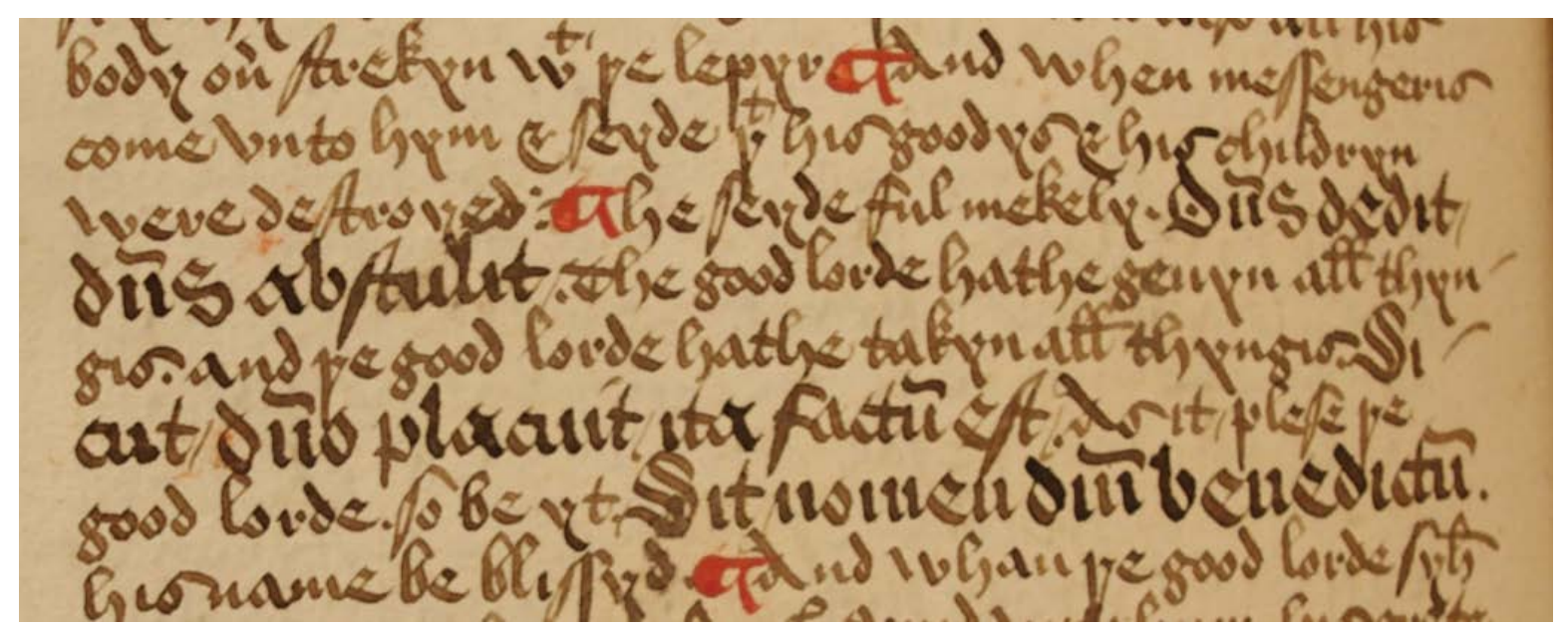

Figure 2: fol. $112^{\mathrm{v}}$, 11.15 - 22. Reproduced by permission of the President and Fellows of Trinity College, Oxford.

Once again, the translation here is less literal than the one we find in the Wycliffite Bible: whilst both EV and LV translate dominus dedit dominus abstulit as the Lord 3af, the Lord took awei and thus translate the Latin syntax very closely, $T$ translates more freely as The good Lorde hathe geuyn alle thyngis, and pe good Lorde hathe takyn alle thyngis (1l. 60526053), adding the object alle thyngis for increased clarity of reference.

\subsubsection{English Translation without Inclusion of the Latin Text}

All of the examples discussed so far mark their status as translations in a number of ways, either by quoting an entire section in Latin and then translating it, by translating sentence by sentence, or by providing a short Latin cue followed by a more extensive translation of material which is not quoted in full. However, there are also extensive passages in $T$ which are translated directly from the Bible without quoting any Latin. For instance, a lengthy section in ll. 4756-4781 contains an account of Abraham's bargaining with God to save the cities Sodom and Gomorrah. This is a translation of Genesis 18:23-33, which a few lines will demonstrate:

\section{[5]}

[4759]،"Lorde, wylt thow destroy a ryghtwys man with a ${ }^{[4760]}$ synner? Lorde, yf pere be fyfty ryghtwis men in pe cyte, wylt not thow safe ${ }^{[4761]}$ pe cyte for fyfty ryghtwys men? God forbede, good Lord, pat thow ${ }^{[4762]}$ shuld slee a ryghtwis man with a wykkyd man. For than a ryghtwis man ${ }^{[4763]}$ shuld be as a synner. Lorde, is not pe worlde thyn good? 
Lorde, doo not pat ${ }^{[4764]}$ wykkyd doom.” Than pe good Lorde answeryd to Abraham

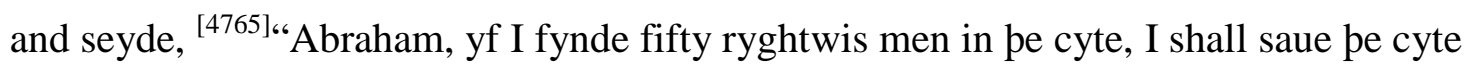
for ${ }^{[4766]}$ tho ryghtwis men.”

\section{Gen 18}

${ }^{23}$ numquid perdes iustum cum impio

${ }^{24}$ si fuerint quinquaginta iusti in civitate peribunt simul et non parces loco illi propter quinquaginta iustos si fuerint in eo

${ }^{25}$ absit a te ut rem hanc facias et occidas iustum cum impio fiatque iustus sicut impius non est hoc tuum qui iudicas omnem terram nequaquam facies iudicium

${ }^{26}$ dixitque Dominus ad eum si invenero Sodomis quinquaginta iustos in medio civitatis dimittam omni loco propter eos

This section is clearly translated directly from the Vulgate and stays relatively close to the Latin source text, apart from a few liberties which the translator takes with the text, such as insertions of names (Abraham, yf I fynde (l. 4765) for si invenero; Lorde, wylt thow destroy (l. 4759) for numquid perdes), replacement of pronouns by nouns (for tho ryghtwis men (1. 4766) for propter eos), and a rather free translation of non est hoc tuum qui iudicias omnem terram as Lorde, is not pe worlde thyn good? (l. 4763). These changes often serve to clarify references in the text and heighten the dramatic qualities of the interchange between God and Abraham, and are thus in keeping with the translation strategies found throughout $T$, as discussed above. However, unlike in the passages previously discussed, here the original language is not given, and in contrast to examples [1]-[2] above, it is not made obvious textually or visually that this is a direct translation from the Vulgate. Only a direct comparison with the Latin would reveal this. Here it seems that English is trusted enough as a medium for conveying the text of Scripture to be allowed to stand alone, as a translation in its own right.

\subsubsection{Latin Quotation without English Translation}

Where $T$ contains Latin quotations, it almost without fail provides English translations, often introduced by the phrase pat is to seye, which indicates that the compiler did not expect all members of his audience to be Latinate. Given this fact, the very few instances where no translation is provided are all the more striking. In some places, specific biblical passages are referred to by their Latin incipits, without a translation: 
[6]

${ }^{[5485]}$ And than Moyses for to make laude and praisyng to God of ther sauff ${ }^{[5486]}$ passage, made thanne this canticle. Cantemus domino gloriose et cetera. ${ }^{[5487]}$ And whan pe pepil of Israell were comyn to londe, pere they ${ }^{[5488]}$ abodyn vij dayes.

This section shows a marked interest in liturgical matters, and presupposes a knowledge of liturgical incipits: Only the opening of the Canticum Moysi (Ex 15:1-19) is given, and the note et cetera indicates the expectation that readers would be able to recite the remainder of the verse from memory. As one of the weekly canticles, the Canticum Moysi was a prominent part of the Divine Office, and would have been well known to clerical members of the audience. ${ }^{20} \mathrm{~A}$ few lines later, the liturgical practices at Salisbury are elaborated upon:

[7]

${ }^{[5494]}$ at pe feste of Pasche pe quere goith a ${ }^{[5495]}$ presessioun abought pe founte vij dayes in pat weke with songe and ${ }^{[5496]}$ melodie, seing In exitu israel de egipto, et cetera

The liturgical procession to the font at Easter described here is attested in early printed Sarum Processionals, which include the singing of the psalm In excitu Israel de Egypto (cf. Figure $3) .^{21}$

\footnotetext{
${ }^{20}$ By contrast, some Wycliffite texts give the incipits of these canticles in both Latin and English. See, for instance, Oxford, Bodleian Library, Fairfax 2 (Solopova 2016b: 138).

${ }^{21}$ On this practice, see also Wickham Legg (1916: 137) and Bailey (1971: 52).
} 


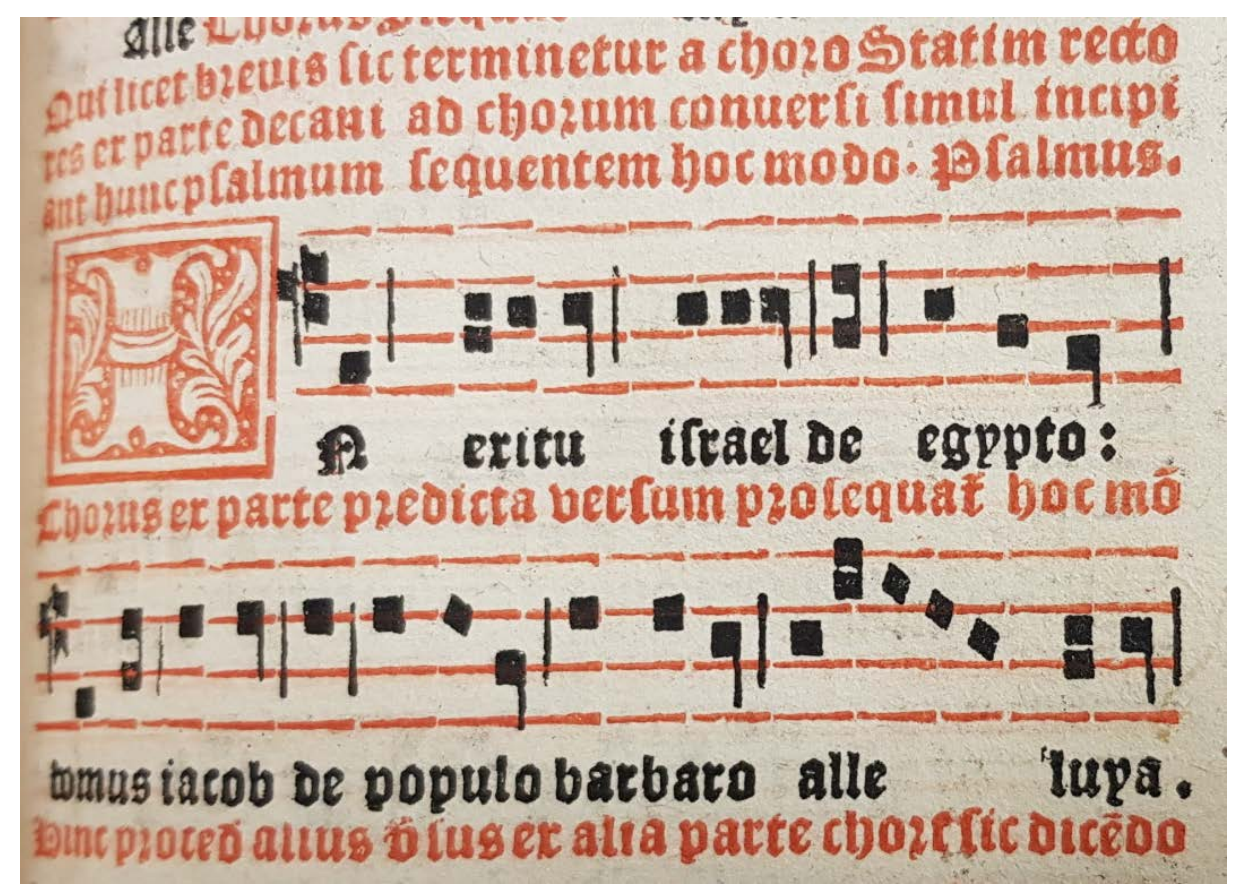

Figure 3: Sarum Processional, printed in 1508 (STC 16233). Corpus Christi College, Oxford, $\Delta .18 .1$, fol. $106^{\mathrm{r}}$. Reproduced by permission of the President and Fellows of Corpus Christi College, Oxford.

As this passage with its focus on liturgical practice would have been of interest mainly to clerical members of the audience, it is likely that the compiler felt that a translation of the titles of psalms was not necessary. It would not have been very useful, either, as the liturgy was performed in Latin, and extant translations of liturgical texts were, as far as we are aware, restricted to epistle and gospel lections as part of the Wycliffite endeavour. ${ }^{22}$ The most recognisable form of such psalm titles was thus their Latin form, which is why the compiler may have foregone an English translation in these cases. ${ }^{23}$

The same explanation cannot be applied, however, to another section where the Latin is quoted without an English translation. This is in a section referring to the Last Supper, where the words of consecration spoken by Christ are only given in Latin:

\footnotetext{
${ }^{22}$ For further details on lectionaries in English, see Solopova (2016b: 6-17). My forthcoming edition of the Wycliffite Old Testament Lectionary with the Early English Text Society contains an extensive analysis of this group of texts and their use. On the use of the psalms in Middle English literature, see also Sutherland (2015).

${ }^{23}$ For further passages in $T$ which show a marked interest in liturgical practice see, for instance, 11 . 1115-1120 (which detail the languages used in the liturgy), and 1l. 5271-5283 (which explain why three Masses are said on Christmas Day).
} 
${ }^{[5927]}$ And pat manna pe whiche oure Lorde gaue to pe childryn of Israell ${ }^{[5928]}$ synyfyeth pe holy brede pe whiche he gaue to his disciplis longe aftyr at his ${ }^{[5929]}$ maundi whan he seyde these wordys, "Accipite et manducate. Hoc est ${ }^{[5930]}$ corpus meum quod pro uobis tradetur."

It is noteworthy that these words remain untranslated and uncommented. The question of transubstantiation was one of the main theological issues contested by the Lollards (Hudson 1988: 281-290). ${ }^{24}$ If the compiler had had any Lollard sympathies, the words spoken at the Last Supper would have been the ideal place to comment upon this issue or to voice Lollard views, as is indeed the case in many Lollard texts. ${ }^{25}$ However, what we find is quite the contrary: not only is there a lack of pertinent commentary or interpretation, but also a lack of translation. It almost seems as if the compiler is unwilling to engage with this controversial issue, and evades the controversy by staying on the safe ground provided by Latin. Here as elsewhere, $T$ appears non-reformist in theological terms, and there is no textual similarity to the Wycliffite translations of this passage.

The compiler of $T$, then, uses a range of different strategies of translating directly from the Vulgate. He gestures towards the Latin source in a variety of ways, ranging from full quotation of the Latin text to complete exclusion of any Latin quotations. His translations are, as a rule, less literal than the Wycliffite translations. He also adapts the biblical text to increase the clarity of reference and immediacy of the narrative. The compiler has no apparent qualms about translating parts of the Vulgate into the vernacular, despite the problematic status of English translations of the Bible in the fifteenth century. It is striking that despite the restrictions on Bible translation at the time, a writer with non-reformist views was thus able to translate extensive sections of biblical material into the vernacular and clearly mark his translations as translations, without any apparent concern about possible repercussions or censorship. In some places Latin cues may have been used to legitimise the presence of a translation, but these cues do not appear consistently in all passages which are translated, and occasionally, Latin quotations remain untranslated. These passages reveal a distinct interest in liturgical practice, and may not have been translated due to practical considerations and in

${ }^{24}$ On this point see also Ghosh (2002: 164-165; 197-200), who discusses some contemporary responses to Wyclif's theology in greater detail.

${ }^{25}$ Such insertions frequently occur in Lollard tracts and commentaries - see, for instance, the 'topics' (e.g. on the Eucharist) in the Wycliffite Glossed Gospels (Hudson 2015: 96-116). 
some places possibly to avoid engaging with contentious theological issues such as the nature of the Eucharist. The presence of translation in almost all cases shows the compiler's distinct interest in biblical material in the vernacular, and indicates that he was conscious of writing for a mixed audience, some members of which were either not Latinate, or at least preferred the vernacular to Latin. This may have been the case with members of the clergy who found the vernacular of practical use for religious instruction. The absence of translations of liturgically relevant phrases as well as the text's general interest in liturgical matters confirms that at least part of the text's audience is likely to have been a clerical one.

\subsection{Summaries of Biblical Texts and Universal History Writing}

$T$ does not only contain direct translations of biblical material. A large part of the biblical material is presented in the form of summaries, keeping the text to an economical length and allowing the compiler to focus on specific aspects of the narrative. The boundaries between word-by-word translation and summary can be blurry, as some passages freely alternate between the two:

[9]

${ }^{\left[{ }^{5303]}\right.}$ Than furthermore we rede in Genesis, capitulo $\mathbf{i i i j}^{\mathbf{0}}$, pat oure Lorde seyde ${ }^{[5304]}$ to Moyses, "What holdys thow in thyn hande?” Moyses answeryd and ${ }^{[5305]}$ seyde, “A rodde.”

Here God's words and Moses's answer are translated literally from the Vulgate (dixit ergo ad eum quid est hoc quod tenes in manu tua respondit virga (Ex 4:2)). The following verse in the Vulgate is: ait proice eam in terram proiecit et versa est in colubrum ita ut fugeret Moyses (Ex 4:3). In T, this is translated rather more freely, omitting the phrase ita ut fugeret Moyses:

\section{[10]}

${ }^{[5305]}$ Oure Lorde bad hym cast it vppon pe erthe. Tho Moyses ${ }^{[5304]}$ dyd as oure Lorde commaundyd hym, and yt was turned into a serpente.

$T$ then proceeds to translate Exodus $4: 4$ in a similarly free fashion, but omits Exodus 4:5-8 completely, before returning to Exodus 4:9, which the compiler summarises: 


\section{[11]}

${ }^{\left[{ }^{5309]}\right.}$ Than seyde oure Lorde, "Yf the pepyll wyl not trowe pe, take water of pe ${ }^{\left[{ }^{5310]}\right.}$ flode and sched fourthe vppon be erthe, and whosoeuer shall drynke of pat

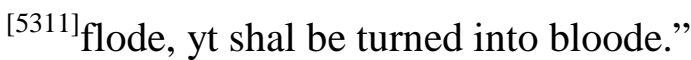

The relevant verse in the Vulgate is more specific regarding the various ways in which the people refuse to listen to Moses:

quod si nec duobus quidem his signis crediderint neque audierint vocem tuam sume aquam fluminis et effunde eam super aridam et quidquid hauseris de fluvio vertetur in sanguinem (Ex 4:9)

In $T$, si nec duobus quidem his signis crediderint neque audierint vocem tuam is rendered simply as Yf the pepyll wyl not trowe pe (1. 5309), which focuses on the Israelites' unbelief but does not specify the dual lack of belief and willingness to listen, which are both emphasised in the Bible. The remainder of the verse is translated more literally, without any omissions. The version of this verse in $T$ thus utilises both close translation and summary of the biblical text. It is, perhaps, more appropriate to see Bible translation in $T$ on a spectrum ranging from close translation to free summary and retelling, than to try and classify the text's approaches to translation into different stable categories. Some of these translations or retellings may be the result of the compiler's recollecting biblical stories from memory, especially through their use in the liturgy, rather than with the Vulgate open in front of him when composing some of these summaries. Key biblical passages such as Genesis 1 would have been readily present in the mind of an educated medieval writer, and direct reference to a copy of the Vulgate would not have been necessary at all times. ${ }^{26}$ For instance, the account of Creation at the very start of the text is a summary based on the beginning of Genesis, rather than a line by line translation of the biblical text:

[12]

${ }^{[1]}$ Almyghty God of his diuine power pat made alle the worlde of nouzt, yt ${ }^{[2]}$ plesyd hym to make man last of alle his werkys. For pe first day, God made ${ }^{[3]}$ aungelis, arcaungelis and heuyn. On pe morwe aftyr pat is callyd Mounday, ${ }^{[4]}$ God made pe firmament, sonne and mone and pe sterris bryght. On pe ${ }^{[5]}$ Twewysday, God made bothe see and land. On

\footnotetext{
${ }^{26}$ On the memorised Bible which educated churchmen and laymen had readily present in their minds, see Beal (2012: 81).
} 
pe Wednysday, God made ${ }^{[6]}$ fisshis in water to swym and foule on londe to flee and seyde, "Cressite et ${ }^{[7]}$ multiplicamini."

This passage is based on Genesis 1, but only summarises the crucial elements of the biblical text. The inclusion of biblical summaries in the universal history in $T$ is part of a longstanding tradition of universal history writing. The Polychronicon and other universal histories in Latin and English likewise contain summaries and translations of key episodes in the Bible. A similar connection between biblical history and world history can be found in other vernaculars, and in this regard, $T$ should be seen in a wider European context. Key examples are the late medieval German Historienbibeln ('story-Bibles'), prose narrative Bibles which add other historical and didactic material (Murdoch 2003: 9). ${ }^{27}$ There is a wide range of different Historienbibeln with significant textual differences, but their main sources include both biblical and para-biblical texts like the Vulgate and Comestor's Historia Scholastica, as well as secular chronicles such as the Weltchroniken by Rudolf von Ems, the Christherrechronik, and others (Gerhardt 1977-2006). Although there seems to be no direct textual influence of such Historienbibeln on $T$, there is a generic overlap between Historienbibeln and universal histories such as $T$. Consequently, there are similarities in the kind of information which both genres tend to include, and in the textual strategies which they use. For instance, $T$ contains a detailed description of the different parts of the world (excerpted from the Polychronicon), and similar descriptions of the world are included in some Historienbibeln, too. ${ }^{28}$

Similarities of a formal kind can also, perhaps, be detected in the opening words of the Historienbibeln, which typically invoke the power of God before moving on to an account of the creation of the world based on Genesis: "Dô Got in siner magenkraft schwebt und alle ding in siner wißhait hett” (Merzdorf 1870: I, 107; 'God in his majesty is above all and holds all things in his wisdom') and "Richer god von himelrich und ertrich und obe allen kreften

\footnotetext{
${ }^{27}$ For a list of manuscripts and descriptions of the Historienbibeln, see Vollmer (1912).

${ }^{28}$ See, for instance, the Historienbibel (of Vollmer's class IIa) edited by Merzdorf (1870: II, 595-900). The story-Bibles also show specific strategies of adapting verse sources to the requirements of a prose historical text, for instance when using verse chronicles like that of Rudolf von Ems as source texts (see Merzdorf (1870: I, 101) for more details on verse sources). As I have discussed elsewhere in relation to the Holy Cross Legend, $T$ uses verse sources in a similar way, adapting them to the prose text but occasionally preserving residual rhyme (Gillhammer 2019).
} 
swebet din kraft” (Merzdorf 1870: II, 595; 'God, Judge of heaven and earth, and your power is above all powers'). ${ }^{29}$ Although there is no direct textual link with $T$, there is a certain similarity with its opening formula and its emphasis on God's power: Almyghty God of his diuine power pat made alle the worlde of noust (l. 1). There is, then, a close connection, between biblical summary and world history, not just in English but also in other European vernaculars. Late-medieval biblical histories are perhaps best seen as different expressions of a common, pan-European textual tradition. As in the Historienbibeln, the biblical summaries in $T$ may have been created with a didactic purpose in mind, in order to make biblical material accessible in the vernacular to a lay audience, or those tasked with the instruction of the laity.

\subsection{Exegetical passages and Exempla}

$T$ also contains eight exegetical passages which expound the biblical material according to its spiritual significance. These sections are typically introduced by Moralite, as in a passage which discusses the significance of Hagar and Sarah in Genesis 16, and starts as follows:

\section{[13]}

${ }^{[4503]}$ Moralite. 3ef ye wyl consydere aftyr be trouthe, by pe chamberer is ${ }^{[4504]}$ vndirstonde pe synagoge of pe Sarasyns and Paynyms. The chamberers ${ }^{[4505]}$ sone be they pat holde and obserue pe lawe perof. Be Sara is vndyrstonde ${ }^{[4506]}$ holy chirche and they pat pe lawe perof holden is vndirstonde Isaac, fygure ${ }^{[4506]}$ of oure Lorde Ihesu Crist.

In this exposition of the allegorical sense, Hagar is equated to the gentiles, whilst Sarah is seen as prefiguring the Church. This passage is similar to contemporary medieval biblical commentaries in terms of content, but unusually, the version in $T$ does not appear to be based directly on any of the principal medieval commentaries. A similar idea occurs, for instance, in the Glossa ordinaria, which interprets Sarah as a symbol of the New Testament, giving birth to the Christian people. ${ }^{30}$ Whilst the idea, then, is conventional, my comparison of $T$ with the key medieval commentaries revealed no exact analogies of content and wording. The version in $T$, therefore, does not appear to be translated directly from any of the existing commentaries, but presents a slightly different exegetical approach to the biblical text. The eight passages in the manuscript which cover such commentary material - moralities and

\footnotetext{
${ }^{29}$ Translations are my own.

${ }^{30}$ Migne (1844-1865: CXIII, col. 122A).
} 
exegetical interpretations - are of a nature which would have been useful for a range of exegetical tasks, and many educated medieval religious writers would have been trained to write texts of this kind. As no direct source can be identified for any of these commentary sections, it is likely that they present the compiler's own version of moral interpretations, perhaps loosely based on a variety of different sources, and certainly informed by a close knowledge of commentary writing and biblical exegesis. ${ }^{31}$

The exegetical interpretations in $T$ connect the literal sense, which is the focus of a great part of the historiographical text, with the spiritual sense of Scripture. The sections introduced by 'Moralite' are primarily concerned with the allegorical sense (as in example [13]) and, in other places, with the tropological sense:

\section{[14]}

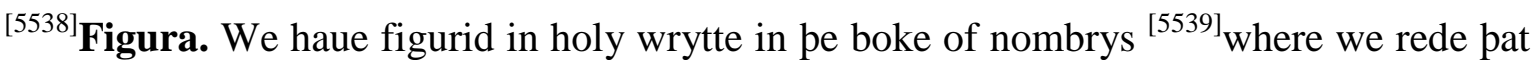
Moyses was ordeyned by God prynce and leder of be ${ }^{[5540]}$ peple of Israell.

Here as in many other exegetical passages, the narrator includes himself as a member of the audience by using the first person plural pronoun we (l. 5538), creating a fictional receptive community in which the exegetical analysis of the biblical text applies both to the audience and the exegete himself. Having established this common ground, the passage, discussing Numbers 10:31, then continues with a translation of Moses's words to Hobab, the son of Raguel:

[15]

${ }^{[5540]}$ 3et he prayde Olyap, pe sone of Raguel, ful mekely sayng, ${ }^{[5541] ، \text { Thow knowest wel }}$ ther be lyons in pe desert where we shal make oure ${ }^{[5542]}$ habytaciouns. I pray pe, be with us, and thow shalt be oure ledere.” And ${ }^{[5543]}$ this was doon in pe desert of Synay goyng

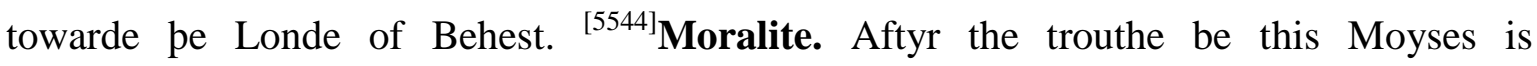
vndirstonde euery creature ${ }^{[5545]}$ pat hathe vppon oper any gouernaunce, be yt spirituelly or temporally. ${ }^{\left[{ }^{5546]}\right.}$ Whiche for pat cause is in honoure and dygnyte, he shulde nat be so proude ${ }^{[5547]}$ pat be his ymagynacioun he shulde wylle to gouerne and rewle alle, but he ${ }^{[5548]}$ shulde take Oliap, pat is as moche to saye as proteccioun, of a creature ${ }^{[5549]}$ from his

\footnotetext{
${ }^{31}$ See Kraebel (2020) on the connection between biblical commentary and translation in late medieval England.
} 
enemye, pe whiche ledyth a man throuh pe deserte of this worlde ${ }^{[5550]}$ vnto be londe of promyssioun, pat is into pe glorie of God.

Ll. 5540 - 5542 are based on the relevant passage in the Vulgate, presented here for comparison:

et ille noli inquit nos relinquere tu enim nosti in quibus locis per desertum castra ponere debeamus et eris ductor noster (Num 10: 31)

It is unclear whether ther be lyons in pe desert (1. 5541) is an addition to the biblical text by way of explaining the dangers of the desert with a more palpable image, or whether this stems from a variant reading of locis as leones. The translation of this section on the whole is rather free, rendering Moses's negative imperative noli nos relinquere as the positive plea I pray pe, be with us (1. 5542), and moving it from its position at the beginning of the verse further towards the end. This translation of the biblical text - the sensus literalis - is introduced by the term Figura (1. 5538, example [14]), distinguishing this section clearly from the following Moralite (l. 5544, example [15]) which expounds the tropological sense as referring to authority and the virtue of humility. The term figura is typically used in sermons when presenting biblical material to illustrate or prove a point by way of an exemplum. ${ }^{32}$ In this way, the inclusion of commentary material in $T$ creates a clear connection with late medieval preaching, which sometimes even includes verbal analogues to how exempla are presented in sermons. This is evident from a passage describing another event in Numbers 25, which likewise introduces the material using the term figure, followed by a reference to the biblical book in question:

[15]

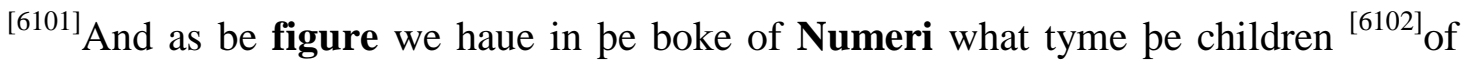
Israell were entryd into pe londe of Moab, they abode a whyle in ${ }^{[6103]}$ Sechym.

The pattern according to which the material is introduced here is remarkably similar to that known from sermon collections. Compare, for instance, a Latin sermon in a collection in

\footnotetext{
${ }^{32}$ On the terminology, see Wenzel (2012: 686) and Wenzel (2005: 321-322). Helen Spencer, however, notes that there was "no great concord over terminology: exemplum, figura, fabula, historia seem often to be approximate synonyms” (1993: 81, n. 16).
} 
Oxford, Bodleian Library, Lat. th. d. 1, which likewise introduces the material as 'figure', followed by a reference to the biblical book in question:

In cuius Figura habitur primo Regum $9^{\circ}$ quia dauid vnctus in regem quesiuit si superesset aliquis de domo saul vt cum eo faceret misericordiam (fol. 164 ${ }^{\mathrm{r}}$ )

A figure of this can be found in 2 Samuel 9, where David, after being anointed king, asked if anyone were left of the house of Saul, so that he might be merciful to him. ${ }^{33}$

T follows this pattern very closely, with its use of the verb "we haue" perhaps imitating the wording in "habitur".

Although the content of the exempla in $T$ is not directly indebted to any known sermon collections, there is a clear similarity between the sermon genre and some sections in $T$. This indicates that the compiler of $T$ is likely to have been trained in the rhetorical art of preaching, which he put to use in his universal history. There was, in fact, a long-standing tradition of universal chronicles including collections of exempla for their lay readers. Ranulf Higden drew on books of exempla when composing the Polychronicon (Taylor 1966: 47), ${ }^{34}$ and English and other vernaculars show the same impulse. As Claudia Wittig (2017) has shown, chronicles of the High Middles Ages frequently draw on exempla to further the moral education of their aristocratic lay readers, as in the Middle High German Kaiserchronik. The inclusion of material of this kind in $T$ ought to be seen very much within this context. The compiler's method of expounding the biblical text according to its spiritual senses and using it as a source of exempla, alongside direct translation and summaries, shows that he interacted with the biblical text on a wide range of different levels, and through the prism of universal history. These textual strategies reflect the desire to make the biblical text accessible and comprehensible to readers who are non-Latinate or not well versed in exegetical intricacies, not only by presenting the material in the vernacular but also by providing explanations of select passages according to their allegorical and tropological senses.

\footnotetext{
${ }^{33}$ This sermon collection is described in Wenzel (2005: 95-99). My translation follows Wenzel (2012: 686).

${ }^{34}$ Higden was well versed in the medieval artes praedicandi, as his treatise Ars componendi sermones shows (Wenzel 2015: 23-24).
} 


\section{Conclusions}

The various ways of interacting with the biblical text which we find in $T$ - translation, summary, retelling, commenting, and referring to its liturgical use - are in line with the looser kinds of engagement with biblical and para-biblical texts found in other fifteenth-century texts which focus on "vernacular theology", 35 and which are marked by the fluidity, adaptability, and range of their use(s) of biblical material. Similar to some other fifteenth-century writers' interaction with biblical material, the compiler of $T$ does not seem to be concerned about possible heretical implications of Bible translation or about the potential censorship which such translation might incur. He rather uses the grey area between Bible translation (in its strict sense) and looser engagement with the text creatively and freely, and without displaying any heterodox tendencies. These types of interaction with the biblical text can be situated within the tradition of universal history writing both in English and in other European vernaculars, and some of the textual characteristics of $T$, such as the prominent inclusion of exegetical material and exempla, mirror the features of the genre more broadly. Texts like $T$ thus give testimony to the multiform and diverse spaces which fifteenth-century culture allowed for vernacular reception of the Bible, particularly in the context of universal history writing. ${ }^{36}$

\footnotetext{
${ }^{35}$ For a discussion of this term, see Johnson (2011). The collection of essays in Gillespie and Ghosh (2011) demonstrate the range of vernacular biblical and theological texts in the fifteenth century.

${ }^{36}$ I am grateful to Professor Daniel Wakelin for his comments on earlier versions of this article. Professor Andrew Kraebel generously shared his expert opinion on the commentary passages in $T$ with me. My gratitude also goes to Helmut Gneuss for his helpful suggestions. I am indebted to the editors and anonymous readers for Anglia, who provided insightful comments on this article.
} 


\section{WORKS CITED}

Bailey, Terence. 1971. The Processions of Sarum and the Western Church. Toronto: Pontifical Institute of Mediaeval Studies.

Beal, Jane. 2012. John Trevisa and the English Polychronicon. Tempe: Arizona Center for Medieval and Renaissance Studies.

De Hamel, Christopher. 2001. The Book: A History of the Bible. London: Phaidon Press Limited. DMLBS = Dictionary of Medieval Latin from British Sources. 2018. Brepols, <dmlbs.ox.ac.uk/web/index.html $>$ [last accessed 5 August 2020].

Dove, Mary. 2007. The First English Bible: The Text and Context of the Wycliffite Versions. Cambridge: Cambridge University Press.

Dove, Mary (ed.). 2010. The Earliest Advocates of the English Bible. Exeter: Exeter University Press.

Edwards, A. S. G. 1980. "The Influence and Audience of the Polychronicon: Some Observations”. Proceedings of the Leeds Philosophical and Literary Society 17 (6): 11319.

Forshall, Josiah and Frederic Madden (eds.). 1850. The Holy Bible: Made from the Latin Vulgate by John Wycliffe and his followers. 4 vols. Oxford: Oxford University Press.

Gameson, Richard. 2018. The Medieval Manuscripts of Trinity College, Oxford: A Descriptive Catalogue. Oxford: The Oxford Bibliographical Society.

Gerhardt, Christoph. 1977-2006. 'Historienbibeln (deutsche)'. In K. Ruh (ed.). Die deutsche Literatur des Mittelalters: Verfasserlexikon. Volume 4. 2nd ed. Berlin: de Gruyter. 67-75.

Ghosh, Kantik. 2002. The Wycliffite Heresy. Authority and the Interpretation of Texts. Cambridge: Cambridge University Press.

Gillespie, Vincent. 2011. 'Chichele's Church: Vernacular Theology in England after Thomas Arundel'. In: Vincent Gillespie and Kantik Ghosh (eds.). After Arundel: Religious Writing in Fifteenth-Century England. Turnhout: Brepols. 3-42. Gillespie, Vincent and Kantik Ghosh (eds.). 2011. After Arundel: Religious Writing in Fifteenth-Century England. Turnhout: Brepols.

Gillhammer, Cosima. 2019. “The Holy Cross Legend: A Unique Version in Oxford, Trinity College, MS 29”. Medium Avum 88: 52-79.

Gillhammer, Cosima. Forthcoming. A Late-Medieval History of the Ancient and Biblical World, edited from Oxford, Trinity College, MS 29. 2 vols. Middle English Texts.

Harris, Kate. 1983. “John Gower’s Confessio Amantis: The Virtues of Bad Texts”. In: Derek Pearsall (ed.). Manuscripts and Readers in Fifteenth-century England: The Literary Implications of Manuscript Study. Essays from the 1981 Conference at the University of York. Cambridge, Totowa, NJ: Brewer. 27-40.

Harris, Kate. 1993. "Ownership and Readership: Studies in the Provenance of the Manuscripts of Gower’s Confessio Amantis.”. Unpubl. PhD dissertation, University of York.

Harris, Kate. 1998. "Unnoticed Extracts from Chaucer and Hoccleve: Huntington MS HM 144, Trinity College, Oxford MS D 29 and The Canterbury Tales”. Studies in the Age of Chaucer 20: 167-99. 
Hudson, Anne. 1988. The Premature Reformation. Wycliffite Texts and Lollard History. Oxford: Clarendon Press.

Hudson, Anne. 2015. Doctors in English. A Study of the Wycliffite Gospel Commentaries. Liverpool: Liverpool University Press.

Hudson, Anne. 2017. 'The Origin and Textual Tradition of the Wycliffite Bible'. In: Elizabeth Solopova (ed). The Wycliffite Bible: Origin, History and Interpretation. Leiden: Brill. 133161.

Hudson, Anne and Elizabeth Solopova. 2017. 'The Latin Text'. In: Elizabeth Solopova (ed). The Wycliffite Bible: Origin, History and Interpretation. Leiden: Brill. 107-132.

Johnson, Ian. 2011. "Vernacular Theology / Theological Vernacular: A Game of Two Halves?” In Vincent Gillespie and Kantik Ghosh (eds.). After Arundel: Religious Writing in Fifteenth-Century England. Turnhout: Brepols. 73-91.

Kennedy, Edward Donald. 1989. Chronicles and other Historical Writing. A Manual of the Writings in Middle English, 1050-1500. Volume 8. New Haven, CTt: Connecticut Acad. of Arts and Sciences.

Kraebel, Andrew. 2020. Biblical Commentary and Translation in Later Medieval England. Cambridge: Cambridge University Press.

MED = Middle English Dictionary. 1952-2001. Ed. Hans Kurath, Sherman M. Kuhn, John Reidy and Robert E. Lewis. Ann Arbor, MI: University of Michigan Press. $<$ http://quod.lib.umich.edu/m/med/> [last accessed 5 August 2020].

Merzdorf, Theodor (ed.). 1870. Die Deutschen Historienbibeln des Mittelalters nach vierzig Handschriften. 2 vols. Tübingen: Fues.

Migne, Jacques-Paul. 1844-1865. Patrologia Latina Database. <http://pld.chadwyck.co.uk/> [last accessed 8 June 2020].

Minnis, A. J., A.B Scott, with the assistance of David Wallace (eds.). 1991. Medieval Literary Theory and Criticism c. 1100-c.1375. The Commentary Tradition. Rev. ed. Oxford: Clarendon.

Moore, Colette. 2011. Quoting Speech in Early English. Cambridge: Cambridge University Press.

Mosser, Daniel. 2010. “A Digital Catalogue of the Pre-1500 Manuscripts and Incunables of the Canterbury Tales”. <http://www.mossercatalogue.net/index.html> [last accessed 31 June 2020].

Murdoch, Brian. 2003. The Medieval Popular Bible: Expansions of Genesis in the Middle Ages. Cambridge: Brewer.

Ogilvie-Thomson, S. J. 1991. The Index of Middle English Prose. Volume 8: A Handlist of Manuscripts containing Middle English Prose in Oxford College Libraries. Cambridge: Brewer.

Parkes, Malcolm B. 1969. English Cursive Book Hands 1250-1500. Oxford: Clarendon Press.

Solopova, Elizabeth. 2016a. “A Wycliffite Bible made for a Nun of Barking”. Medium Avum 85: 77-96.

Solopova, Elizabeth. 2016b. Manuscripts of the Wycliffite Bible in the Bodleian and Oxford College Libraries. Liverpool: Liverpool University Press. 
Solopova, Elizabeth (ed.). 2017. The Wycliffite Bible: Origin, History and Interpretation. Leiden: Brill.

Spencer, Helen Leith. 1993. English Preaching in the late Middle Ages. Oxford: Clarendon; Oxford University Press.

Sutherland, Annie. 2015. English Psalms in the Middle Ages, 1300-1450. Oxford: Oxford University Press.

Taylor, John. 1966. The Universal Chronicle of Ranulph Higden. Oxford: Clarendon.

Vollmer, Hans. 1912. Materialien zur Bibelgeschichte und religiösen Volkskunde des Mittelalters. Volume 1. Berlin: Weidmannsche Buchhandlung.

Wakelin, Daniel. 2014. Scribal Correction and Literary Craft. English Manuscripts 13751510. Cambridge: Cambridge University Press.

Watson, Nicholas. 1995. "Censorship and Cultural Change in Late-Medieval England: Vernacular Theology, the Oxford Translation Debate, and Arundel's Constitutions of 1409”. Speculum 70 (4): 822-64.

Weber, Robert and Roger Gryson (eds.). 2007. Biblia sacra iuxta vulgatam versionem. 5th ed. Stuttgart: Deutsche Bibelgesellschaft.

Wenzel, Siegfried. 2005. Latin Sermon Collections from Later Medieval England: Orthodox Preaching in the Age of Wyclif. Cambridge: Cambridge University Press.

Wenzel, Siegfried. 2012. “The Use of the Bible in Preaching”. In: Richard Marsden and Ann E. Matter (eds.). The New Cambridge History of the Bible. Volume 2: From 600 to 1450. Cambridge: Cambridge University Press. 680-92.

Wenzel, Siegfried. 2015. Medieval Artes Praedicandi: A Synthesis of Scholastic Sermon Structure. Toronto: University of Toronto Press for The Medieval Academy of America.

Wickham Legg, J.W. 2016. The Sarum Missal. Edited from Three Early Manuscripts. Oxford: Clarendon.

Wittig, Claudia. 2017. "Political Didacticism in the Twelfth Century: the Middle-High German Kaiserchronik”. In: Michele Campopiano and Henry Bainton (eds.). Universal Chronicles in the High Middle Ages. University of York: York Medieval Press. 95-120. 